Микола Петрович Думенко (кандидат військових наук)

Генеральний штаб Збройних Сил Украӥни, Київ, Украӥна

\title{
МЕТОДИЧНИЙ ПІДХІД ДО ОЦІНЮВАННЯ ЕФЕКТИВНОСТІ СИСТЕМИ КОМПЛЕКТУВАННЯ ПЕРСОНАЛОМ ЗБРОЙНИХ СИЛ УКРАЇНИ В УМОВАХ ГІБРИДНОЇ ВІЙНИ (ОСОБЛИВОГО ПЕРІОДУ)
}

У статті розглядаються методичні підходи формалізаиії оиінювання елементів системи комплектування особовим складом Збройних Сил України. Проведений вибір показників, критеріїв $i$ методичного апарату для отримання оцінок у потрібних періодах комплектування.

Ключові слова: персонал, комплектування, оцінювання ефективності, призов, підготовка персоналу.

\section{Ветуп}

Постановка проблеми. Виклики, які постали перед Збройними Силами України (ЗС України) щодо збереження i нарощування бойового потенціалу, вимагають створення дієвих механізмів формування кадрового потенціалу 3С, здатного відповісти на сучасні і прогнозовані загрози.

Стаття присвячена проблемі якісного оцінювання комплектування персоналом 3С України в умовах гібридної війни (особливого періоду).

Аналіз останніх досліджень і публікацій. Актуальність вдосконалення системи комплектування персоналом 3С України визначається в Указах і виступах Президента України [1], [2], наказах Міністерства оборони України [3] та наукових працях багатьох вчених [5]-[7].

Обраний шлях переходу ЗС України до стандартів НАТО вимагає удосконалення існуючої системи комплектування персоналом (СКП) 3С України за підходами передових країн Свропи [4].

У роботі [4] визначені сучасні підходи до оцінювання i прогнозування розвитку кадрового потенціалу і проведення кадрового менеджменту в країнах Свропи, розкрита актуальність кадрового менеджменту для забезпечення розвитку організацій і суспільства у цілому.

У роботах [5], [6] приведені методичні підходи до оцінювання функціонування кадрових органів за напрямками завдань, що вони виконують, підвищення ефективності функціонування СКП, оцінюванню ефективності роботи кадрових органів.

У роботі [7] розроблена методика оцінювання результатів функціонування існуючої системи комплектування ЗС України 3 метою прийняття обгрунтованих рішень щодо вибору варіантів іiі побудови.
Це вказує, що проблема комплектування персоналом 3С України активно досліджується і підкреслює актуальність цього напрямку.

Особливої значущості набувають ці дослідження в умовах особливого періоду i обмежених людських ресурсів для потрібного поповнення висококваліфікованого персоналу 3С України.

Вказані роботи надають аналіз методів i підходів, які дозволяють отримати якісні оцінки результатів функціонування елементів СКП, системи кадрового менеджменту, або кадрових органів, проте у вказаних роботах не наводиться аналіз методів, які б дозволили отримувати кількісні оцінки функціонування СКП ЗС України на періоді виконання завдань ЗС України.

Мета статті - розробити метод оцінювання функціонування системи комплектування персоналом 3С України, який би дозволив отримувати узагальнену оцінку результатів комплектування персоналом 3С України у потрібному періоді функціонування та за i.i складовими.

\section{Виклад основного матеріалу дослідження}

Під системою комплектування персоналом (СКП) ЗС України (ЗС України) розуміється: сукупність органів військового управління $3 \mathrm{C}$ України, органів управління персоналом (кадрових органів) 3С України; підготовлений персонал 3С України; резерви персоналу 3С України (у тому числі того, що проходить підготовку у закладах освіти) i мобілізаційний ресурс Держави; законодавчої i нормативної бази, що визначає організацію i функціонування (взаємозв'язки) СКП. СКП входить до складу ЗС України i взаємодіє 3 системами ресурсного забезпечення Держави (у тому числі соціального і фінансового забезпечення тощо). 
Результати

функціонування

СКП використовують системи бойового застосування військ (сил) 3С України і інші силові відомства (цивільні системи) у яких використовується підготовлений в армії персонал тощо.

Метою функціонування СКП в умовах гібридної війни (особливого періоду) $\epsilon$ забезпечення бойової готовності органів військового управління, військових частин, підрозділів ЗС України за складовою укомплектованості і підготовки персоналу у визначений період виконання завдань за призначенням у встановлених штатах $(01,51,52$, 53).

Метою оцінювання ефективності функціонування СКП $є$ визначення шляхів забезпечення бойової готовності органів військового управління, військових частин, підрозділів ЗС України за складовою укомплектованості і підготовки персоналу у визначений період виконання завдань за призначенням.

Слід зазначити, що динаміка змін чисельності персоналу i динаміка змін обсягів втрачання i поповнення чисельності персоналу різні i змінюються, а тому неможливо забезпечити утримання чисельних значень показників укомплектованості персоналом на одному рівні постійно.

Фактори, що впливають на зниження укомплектованості військових формувань:

звільнення військовослужбовців, що відслужили встановлені терміни, включно із закінченням термінів контракту;

звільнення військовослужбовців за станом здоров'я та іншими обставинами, що надають право на звільнення;

переведення військовослужбовців в межах 3С України, в межах видів 3С України), в межах військових частин і з'єднань;

невірні і несвоєчасні управлінські рішення, тощо.

Вплив цих факторів враховується при розрахунках значень чисельності списочного складу у поточний час або на періоді оцінювання.

Джерелами поповнення чисельності підготовленого персоналу для комплектування військових частин і підрозділів видів ЗС України в особливий період $є$ :

призов підготовленого персоналу 3 складу резерву i військовозобов'язаних, що пройшли службу на відповідних посадах у військах, звільнені і відповідають вимогам щодо призиву на посади за призначенням;

призов i підготовка цивільних осіб у навчальних закладах;

призов і підготовка цивільних осіб у військових навчальних підрозділах;

призов і підготовка цивільних осіб у військових частинах; переведення (перерозподілу) осіб персоналу між видами, військовими частинами ЗС України.

Джерелами поповнення чисельності підготовленого персоналу для комплектування командного складу військових частин і підрозділів видів ЗС України є:

відбір 3 військових частин і підрозділів i підготовка у вищих навчальних закладах (ВВНЗ), курсах підвищення кваліфікації військовослужбовців видів ЗС України;

призов на військову службу під час мобілізації та переатестація сержантів (старшин) із вищою освітою не нижче “бакалавр”);

просування по службі офіцерів згідно з планом резерву.

Джерелами поповнення чисельності підготовленого персоналу для комплектування сержантського складу військових частин i підрозділів видів 3С України є: відбір з військових частин і підрозділів і підготовка у навчальних частинах (підрозділах) військовослужбовців видів ЗС України.

Джерелами поповнення чисельності підготовленого персоналу для комплектування рядового складу військових частин і підрозділів видів ЗС України є: призов цивільних i ïx підготовка у навчальних підрозділах військових частин видів 3С України.

Всі вказані джерела мають свою кількість i часові обмеження забезпечення потрібної чисельності персоналу, які необхідно враховувати на протязі усього періоду планування комплектування 3С України i потребують окремого дослідження. Особливості комплектування військових частин за багатоіндексними штатами потребують їх врахування у динаміці змін чисельності персоналу на штатах з різними індексами 53, 52, 5101.

Ефективність функціонування СКП оцінюється в два етапи:

на першому оцінюється ефективність функціонування складових СКП (органів військового управління ЗС України; органів управління персоналом 3С України, резервів персоналу 3С України; мобілізаційного ресурсу Держави; законодавчої і нормативної бази);

на другому етапі оцінюється ефективність СКП у цілому.

Основними припущеннями при оцінюванні ефективності системи комплектування особовим складом ЗС України в умовах гібридної війни (особливого періоду) можливо обрати наступні:

за період оцінювання характер військових загроз для України не буде змінений;

ЗС України збережуть структуру і чисельність, що встановлена на законодавчому рівні;

система підготовки персоналу збереже існуючу структуру, склад, і порядок підготовки;

оцінювання ефективності СКП проводиться у ланках від військової частини і вище. 
Основним критерієм оцінювання укомплектованості органів управління, військових частин і підрозділів ефективності СКП у цілому, а також iï складових є перевищення значення (K) співвідношення чисельності підготовленого персоналу (S) до штатної чисельності військового часу $\left(\mathrm{S}_{\mathrm{B}}^{\text {Штат }}\right)$ органів управління, військових частин і підрозділів 3 урахуванням військовооблікових спеціальностей і відмінностей у штатах різних індексів. Особливості комплектування управлінь, військових частин і підрозділів враховуються у встановлених нормах укомплектованості (нормативних документах) (К).

$$
\begin{aligned}
& \mathrm{K}_{\mathrm{y}} \leq \frac{\mathrm{S}_{\mathrm{y}}^{\text {Список }}}{\mathrm{S}_{\mathrm{B}(\mathrm{Y})}^{\text {Штат }}} \cdot 100 \%, \quad \mathrm{~K}_{\mathrm{B} / \mathrm{\Psi}} \leq \frac{\mathrm{S}_{\mathrm{B} / \mathrm{Y})}^{\text {Список }}}{\mathrm{S}_{\mathrm{B}(\mathrm{B} / \mathrm{\Psi})}^{\amalg \mathrm{T}}} \cdot 100 \%, \\
& \mathrm{~K}_{\Pi} \leq \frac{\mathrm{S}_{\Pi}^{\text {Список }}}{\mathrm{S}_{\mathrm{B}(\text { п) }}^{\text {Штат }}} \cdot 100 \%
\end{aligned}
$$

де $\mathrm{K}-$ нормативно встановлене значення співвідношення укомплектованості (встановлюється у відсотках) управління (У), військової частини (в/ч), підрозділу (п);

$\mathrm{S}^{\text {Список }}$ - чисельність особового складу за списком (при наявності обмежень на укомплектованість за спеціальностями визначається окремо для визначальних спеціальностей);

$\mathrm{S}^{\text {Штат }}$ - кількість посад за штатом (при наявності обмежень на укомплектованість за спеціальностями визначається окремо для визначальних спеціальностей).

Рівень укомплектованості оцінюється окремо у поточний час tпот і плановому періоді (періодах) застосування 3С України (Тпл).

Період оцінювання можливо запропонувати 5 років, як такий, за який забезпечується підготовка офіцерів у ВВНЗ, і який є найбільш тривалим 3 періодів підготовки військових фахівців. Дискретність проведення оцінювань можливо запропонувати проводити один раз на рік (півроку) $\Delta$ Тоцін $=(0 ; 0,5 ; 1 ; 1,5 ; 2 ; 2,5 ; 3 ; 3,5 ; 4 ; 4,5 ; 5)$.

СКП має забезпечувати підтримання Ку, Квч, Кп на рівні не менше ніж заданий за весь період оцінювання.

Пропонуються наступні показники і критерії оцінювання ефективності складових СКП.

1) Роботу органів військового управління щодо укомплектування персоналом підлеглих військових частин i підрозділів оцінювати показником неукомплектованості персоналу для забезпечення боєздатності підлеглих військових частин (підрозділів) за період оцінювання Су, Свч, Сп.

Критерій оцінювання ефективності органів військового управління щодо укомплектування персоналом підлеглих військових частин i підрозділів $\epsilon$ - не перевищення граничного значення небоєздатних підрозділів (Bg) за показником укомплектованості персоналом, яке встановлено нормативно.

2) Органи управління персоналом (кадрові органи) щодо укомплектування персоналом підлеглих військових частин і підрозділів оцінювати показником - чисельність персоналу, що призначений (непризначений) 3 дотриманням усіх вимог до призначення персоналу на посади за призначенням Fy, Fвч, Fп.

Критерій оцінювання ефективності органу управління персоналом (кадрових органів) $\epsilon-$ не перевищення кількості порушень призначення (не призначення) персоналу, що стали причиною небоєздатності підрозділу.

3) Підготовлений персонал 3С України оцінюється за показником - списочна чисельність персоналу, що призначений на посади Sсписок.

Критерій оцінювання підготовленого персоналу 3С України є забезпечення боєздатності військових частин і підрозділів за показником «персонал», яке встановлено нормативно.

4) Резерви персоналу та мобілізаційного ресурсу оцінювати показником - чисельність персоналу, що забезпечує боєздатність частин (підрозділів) які сформовані або доукомплектовані (можуть бути сформовані або доукомплектовані) за рахунок резервів окремо управління (Sу рез), військових частин (Sвч рез), підрозділів (Sп рез).

Критерій оцінювання резервів персоналу та мобілізаційного ресурсу $\epsilon$ забезпечення боєздатності військових частин і підрозділів за показником «персонал» укомплектування заданої кількості кількість боєздатних (Bg) за показником укомплектованості персоналом, яке встановлено нормативно.

5) Показник оцінювання ефективності законодавчої (нормативної бази) - чисельність персоналу, яка дозволяє забезпечити боєздатність військ у видах, родах і спеціальних військах $3 \mathrm{C}$ України, за період оцінювання (S+Speз).

Критерій оцінювання ефективності законодавчої (нормативної бази) $\epsilon$ - утримання на потрібному рівні чисельності військ у видах, родах i спеціальних військах 3С України, за період оцінювання.

Значення вказаних показників враховуються для визначення чисельності персоналу яка забезпечена, або буде забезпечена 3 використанням можливостей усіх складових.

Враховуючи, що у випадку небоєздатності органу військового управління, військової частини або підрозділу кожен 3 них не допускається до виконання завдань за призначенням можливо вважати, що весь персонал сформований невірно і його чисельність не можна зараховувати до позитивно укомплектованого персоналу. Тому для загального оцінювання ефективності СКП можливо використовувати показник, який 
враховує негативні i позитивні результати комплектування персоналом.

Готовність органів управління (Аi), військових частин (An) (підрозділів) (Am) до застосування вимірюється показниками їх готовності до виконання завдань за призначенням, що мають дискретні значення: 1 (готові) або 0 (не готові). Ці значення враховуються для визначення чисельності персоналу, що буде зарахована для позитивного або негативного оцінювання результату функціонування СКП.

Для вказаних показників i критеріїв оцінювання складових СКП можливо визначити загальні показники оцінювання ефективності функціонування СКП у поточний час (tпот) і за період оцінювання (Тоцін.)

$$
\begin{aligned}
& \mathrm{W}_{\mathrm{y}_{\mathrm{t}_{\text {not }}}}=\frac{\mathrm{S}_{\mathrm{y}}^{\text {Список }}-\mathrm{C}_{\mathrm{y}}}{\mathrm{S}_{\mathrm{y}}^{\text {Штат }}} . \\
& \mathrm{W}_{\mathrm{B} / \mathrm{\Psi}_{\mathrm{t}} \text { not }}=\frac{\mathrm{S}_{\mathrm{B} / \mathrm{\Psi}}^{\text {Список }}-\mathrm{C}_{\mathrm{B} / \mathrm{\Psi}}}{\mathrm{S}_{\mathrm{B} / \mathrm{\tau}}^{\text {Штат }}} . \\
& \mathrm{W}_{\text {підр }} \mathrm{t}_{\text {not }}=\frac{\mathrm{S}_{\text {підр }}^{\text {Список }}-\mathrm{C}_{\text {підр }}}{\mathrm{S}_{\text {підр }}^{\text {Штат }}} .
\end{aligned}
$$

Наприклад: для оцінювання ефективності функціонування СКП полку із забезпечення персоналом підлеглих підрозділів, при $\mathrm{S}_{\text {підр }}^{\text {Штат }}=400,, \quad \mathrm{~S}_{\text {підр }}^{\text {Список }}=300, \quad$ одним небоєздатним підрозділом за показником персонал $\mathrm{C}_{\text {підр }}=70$ (списочна чисельність всього підрозділу н зараховується у позитивну оцінку), то значення узагальненого показника оцінювання Wпідр $=0,575$.

Такі ж оцінки робляться для військових частин у складі ОК, але при наявності небоєздатної частини до позитивної оцінки не зараховується списочна чисельність полку.

Наприклад: для оцінювання ефективності функціонування СКП ОК із забезпечення персоналом підлеглих військових частин, при $\mathrm{S}_{\mathrm{B} / \mathrm{ч}}^{\text {Штат }}=3000, \quad \mathrm{~S}_{\mathrm{B} / \mathrm{ч}}^{\text {Список }}=2300, \quad$ однією небоєздатною військовою частиною за показником персонал $\mathrm{C}_{\text {підр }}=1800$ (списочна чисельність всього полку не зараховується у позитивну оцінку), то значення узагальненого показника оцінювання $\mathrm{WB} / \mathrm{ч}=0,17$.

Такі ж оцінки робляться для оцінювання ефективності СКП із укомплектування підрозділів військових частин у складі ОК, але при наявності небоєздатних підрозділів до позитивної оцінки не зараховується списочна чисельність усіх небоєздатних підрозділів.

Наприклад: для оцінювання ефективності функціонування СКП ОК із забезпечення персоналом підрозділів підлеглих військових частин, при $\mathrm{S}_{\sum \text { підр }}^{\text {Штат }}=2500, \mathrm{~S}_{\sum \text { підр }}^{\text {Список }}=2000$, два небоєздатних підрозділу за показником персонал $\mathrm{C}_{\sum \text { підр }}=140$ (списочна чисельність двох підрозділів не зараховується у позитивну оцінку), то значення узагальненого показника оцінювання Wпідр $=0,24$.

Вказані приклади показують можливість враховування важливість збереження боєздатності частин і підрозділів за вказаним показником i дозволяють оцінювати варіанти їх комплектування.

При проведенні оцінювання на певному періоді (Тоцін.) проводиться усереднені значення W y період $\Delta$ Тоцін $=(0 ; 0,5 ; 1 ; 1,5 ; 2 ; 2,5 ; 3 ; 3,5 ; 4 ; 4,5$; $5)$ із визначенням значення показника на кожному інтервалі оцінювання.

При оцінюванні підрозділів, у яких не виконані вимоги до комплектування усіх категорій посад, їх чисельність враховується, як незабезпечена СКП, та при сумарному оцінюванні буде дозволяти отримати значення відносних оцінок ефективності СКП з укомплектування персоналом підрозділів за їх призначенням.

При оцінюванні військових частин, у яких не виконані вимоги до комплектування підпорядкованих підрозділів, i їх чисельність вплинула на перехід частини у небоєздатний стан, уся чисельність персоналу військової частини враховується, як незабезпечена СКП, та при сумарному оцінюванні буде дозволяти отримати значення відносних оцінок ефективності СКП 3 укомплектування персоналом військових частин за їх призначенням.

При оцінюванні з'єднання (об'єднання), у яких не виконані вимоги до комплектування підпорядкованих частин (підрозділів), i чисельність вплинула на перехід з'єднання (об'єднання) у небоєздатний стан, уся чисельність персоналу з'єднання (об'єднання) враховується, як незабезпечена СКП, та при сумарному оцінюванні буде дозволяти отримати значення відносних оцінок ефективності СКП 3 укомплектування персоналом з'єднань (об'єднань).

При оцінюванні виду ЗС, у яких не виконані вимоги з укомплектування персоналом військових частин, з'єднань (об’єднань), і їх чисельність вплинула на перехід виду ЗС у небоєздатний стан, уся чисельність персоналу виду ЗС враховується, як незабезпечена СКП, та при сумарному оцінюванні буде дозволяти отримати значення відносних оцінок ефективності СКП 3 укомплектування персоналом видів 3С.

Оцінювання укомплектування персоналом ЗС у цілому здійснюється за усередненими оцінками виконання вимог до укомплектованості вище вказаних військових формувань, 3 урахуванням ваги кожної складової у результаті загального комплектування персоналом 3С. 
Загальним показником оцінювання ефективності функціонування СКП за усіма вище вказаними складовими $є$ зважена сума значень вказаних показників за період застосування 3С України (Тпл):

Wперсонал $=(\mathrm{V} 1 \mathrm{Wy}+\mathrm{V} 2$ Wв/ч +V3 Wпідр)/3.

Визначення функцій вагових коефіцієнтів К потребує додаткового аналізу зміни їх значень за період застосування ЗС. На початковому етапі для вибору вагових коефіціентів (V) можливо використовувати метод експертних оцінок, але у подальшому ї необхідно уточнювати 3 урахуванням практично отриманих результатів (наприклад на навчаннях або за результатами бойового застосування військ).

Оцінювання ефективності функціонування СКП необхідно здійснювати за складовими забезпечення укомплектованості підрозділів, військових часин, з'єднань (об'єднань) родів

військ видів ЗС за динамікою їх змін у часі, у відповідному періоді комплектування 3С. Таке оцінювання наддасть наближену оцінку відповідності загальної укомплектованості ЗС потребам.

Критерій оцінювання ефективності функціонування СКП $є-$ не зменшення (утримання) потрібного рівня чисельності боєздатних органів військового управління, військових частин, підрозділів у видах, родах і спеціальних військах ЗС України, за період застосування 3С. Визначення потрібного рівня чисельності боєздатних органів військового управління, військових частин, підрозділів потребує додаткових досліджень, а для оцінювання ефективності функціонування СКП використовуються нормативно встановлені значення.

Вказаний підхід дозволяє отримати кількісні оцінки ефективності функціонування СКП.

Наприклад:

\begin{tabular}{|l|l|l|l|l|l|}
\hline Найменування & $\begin{array}{c}\text { Не } \\
\text { готові по } \\
\text { показнику } \\
\text { «Персонал» }\end{array}$ & $\mathrm{S}_{\sum}^{\text {Штат }}$ & $\mathrm{S}_{\sum}^{\text {Список }}$ & $\mathrm{C}_{\Sigma}$ & $\mathrm{W}$ \\
\hline За 1-й ОК & & 1020 & 835 & 435 & 0,39 \\
\hline 301 полк & & 340 & 280 & 0 & 0,82 \\
\hline 302 полк & 1 & 340 & 325 & 10 & 0,35 \\
\hline Управління & 1 & 10 & 4 & 0 & 0,72 \\
\hline 302 полк & & 340 & 230 & 110 & 0,81 \\
\hline 304 полк & & 110 & 50 & 0 & \\
\hline 3041 рота & 1 & 110 & 80 & 90 & \\
\hline 3042 рота & & 110 & 90 & & \\
\hline
\end{tabular}

Аналіз результатів оцінювання ефективності функціонування СКП 1-го ОК показує, що у 304 полку вона була найнижчою, але є резерви для відновлення готовності 304 полку за рахунок 301 i 302 полків. Разом 3 цим для відновлення готовності управління 302 полку необхідно втручання СКП вищого рівня.

\section{Висновки й перспективи подальших досліджень}

Розроблений методичний підхід до оцінювання ефективності функціонування СКП ЗС України дозволяе отримувати кількісні оцінки ефективності функціонування складових СКП і системи у цілому як у поточний час, так і на періоді виконання завдань ЗС України.

Окремим напрямком подальших досліджень $є$ встановлення залежності i методики прогнозування змін кількісного і якісного складу підготовленого персоналу від конкретних спроможностей держави із забезпечення людськими резервами і системи підготовки персоналу 3С України із підготовки i перепідготовки персоналу за потрібний період підготовки ЗС України до виконання завдань.
Зміна стану забезпеченості персоналом 3С України має інертний характер (від 1 року до 5-10 років) і залежить від багатьох факторів, що мають різну фізичну природу і одиниці вимірювання, але ïx усіх необхідно враховувати для оцінювання функціонування СКП і прогнозу стану СКП на періоді оцінювання.

Результати оцінювання функціонування СКП мають забезпечувати можливість обгрунтування шляхів максимального використання кадрових резервів і системи їх підготовки для забезпечення максимальної боєздатності військ у потрібний період застосування ЗС України.

Для забезпечення позитивних (потрібних) змін у забезпеченні персоналом потрібно забезпечувати постійний моніторинг і аналіз поточного стану СКП, можливих змін і прогнозу стану резервів i укомплектованості ЗС України у подальшому на періоді оцінювання.

Оперативне оцінювання ефективності функціонування СКП, отримання i доведення результатів до органів військового управління для прийняття рішень можливо із використанням автоматизованих систем управління обліком i планування розвитку персоналу. Методики, що 
розробляються за цим напрямком дозволять реалізувати сучасні підходи країн Європи до формування перспективного кадрового потенціалу ЗС України.

\section{Лimepamypa}

1. Указ Президента України № 22/2019 «Про звільнення в запас військовослужбовців строкової служби, строки проведення чергових призовів та чергові призови громадян України на строкову військову службу у 2019 році». [Електронний ресурс]. - Режим доступу: https://www.president.gov.ua/documents/22201925982. 2. Основні оборонні аспекти доповіді Президента України щодо підвищення обороноздатності України 07.2014 р. [Електронний ресурс]. - Режим доступу: https://www.president.gov.ua. 3. Концепція військової кадрової політики у Збройних Силах України на період до 2020 року, затверджена наказом Міністерства оборони України від 26.06.2017 № 342 . 4. COMMON ASSESSMENT FRAMEWOR 2014 рік [Електронний ресурс]. - Режим доступу: https://www.eipa.eu/product/common-assessment-frameworkcaf/. 5. Семененко О. М. Методика воєнноекономічного оцінювання результатів виконання заходів програм розвитку Збройних Сил України за плановий рік / О. М. Семененко // 3б. наук. пр. ЦНДІ ЗС України № 3 (53). - К.: ЦНДІ ЗС України, 2010. - С. 217-226. 6. Кадрова політика в Збройних Силах України: історія, досвід, методологія: монографія / за редакцією О.В. Яцино, О.В. Коня. - К.: ДКП МО України, НМЦ КП МО України, 2011. - 239 с. 7. Водчиць О. Г., Семененко О. М., Добровольський Ю. Б., Бердочник А. Д. Методика оцінки ефективності функціонування систем (органів) комплектування Збройних Сил України особовим складом // Наука і техніка Повітряних Сил Збройних Сил України. 2014. - $\quad$ № 3 (16). $\quad-\quad$ C. 14-17.

\title{
МЕТОДИЧЕСКИЙ ПОДХОД К ОЦЕНКЕ ЭФФЕКТИВНОСТИ СИСТЕМЫ КОМПЛЕКТОВАНИЯ ПЕРСОНАЛОМ ВООРУЖЕННЫХ СИЛ УКРАИНЫ В УСЛОВИЯХ ГИБРИДНОЙ ВОЙНЫ (ОСОБОГО ПЕРИОДА)
}

\author{
Николай Петрович Думенко (кандидат военных наук)
}

\section{Генеральний штаб Вооруженных Сил Украины, Киев, Украина}

В статье рассматриваются методические подходы формализации оценки элементов системы комплектования личным составом Вооруженных Сил Украины. Проведенный выбор показателей, критериев и методического аппарата для получения оценок в нужных периодах комплектования.

Ключевые слова: персонал, комплектование, оценка эффективности, призыв, подготовка персонала.

\section{METHODOLOGICAL APPROACH TO ASSESSING THE EFFECTIVENESS OF THE STAFFING SYSTEM OF THE ARMED FORCES OF UKRAINE IN A HYBRID WAR (SPECIAL PERIOD)}

\author{
Mykola Dumenko (Candidate of Military Sciences)
}

\section{General Staff of the Armed Forces of Ukraine, Kyiv, Ukraine}

The methodological approaches of formalizing the assessment of elements of the manning system of the Armed Forces of Ukraine are considered in the article. The selection of indicators, criteria and methodological apparatus for obtaining estimates in the necessary periods of acquisition was conducted.

Keywords: personnel, staffing, performance evaluation, appeal, staff training.

\section{References}

1. Presidential Decree No. 22/2019 "On dismissal of conscripts, term of holding regular conscripts and regular recruits of Ukrainian citizens for conscription in 2019", Access: https://www.president.gov.ua/documents/22201925982 2. Main defense aspects of the President of Ukraine report on enhancing Ukraine's defense capability 07.2014, Access: https://www.president.gov.ua. 3. Концепція військової кадрової політики у Збройних Силах України на період до 2020 року, затверджена наказом Міністерства оборони України від 26.06.2017 № 342. 4. Common Assessment Framework 2014, Access: https://www.eipa.eu/product/common-assessment-frameworkcaf/ 5. Semenenko O.M. (2010), Methods of militaryeconomic evaluation of actions implementation results of the Armed Forces of Ukraine development programs for the planning year. [Metodyka voienno-ekonomichnoho otsiniuvannia rezultativ vykonannia zakhodiv prohram rozvytku Zbroinykh Syl Ukrainy za planovyi rik], 3b. nauk. pr. TsNDI ZS Ukrainy, Kyiv, pp. 217-226. 6. Personnel policy in the Armed Forces of Ukraine: history, experience, methodology: monograph (2011), [Kadrova polityka $v$ Zbroinykh Sylakh Ukrainy: istoriia, dosvid, metodolohiia: monohrafiia], DKP MO Ukrainy, NMTs KP MO Ukrainy, 239 p. 7. Vodchyts O.H., Semenenko O.M., Dobrovolskyi Y.B. (2014), Methods of assessing the effectiveness of functioning of systems (bodies) of staffing of the Armed Forces of Ukraine with personnel. [Metodyka otsinky efektyvnosti funktsionuvannia system (orhaniv) komplektuvannia Zbroinykh Syl Ukrainy osobovym skladom], Nauka i tekhnika Povitrianykh Syl Zbroinykh Syl Ukrainy, Kharkiv, №3 (16), pp. 14-17. 